\title{
OBJEK EVALUASI PENDIDIKAN
}

\author{
Suddin Bani \\ Fakultas Tarbiyah dan Keguruan UIN Alauddin Makassar \\ Kampus II: Jalan Sultan Alauddin Nomor 36 Samata-Gowa \\ Email: suddin_elbani@yahoo.co.id
}

\begin{abstract}
Abstrak:
Evaluasi merupakan alat yang dipergunakan untuk mengukur tingkat keberhasilan sebuah program. Dalam mengukur sesuatu, harus menggunakan alat ukur yang tepat berdasarkan indikator yang ada. Evaluasi dalam pendidikan bertalian dengan kegiatan atau proses pendidikan yang dijadikan pusat perhatian. Yang dijadikan objek peniliaian yaitu kognitif (pengetahuan dan pengertian), afektif (sikap dan cita-cita), dan psikomotoris (keterampilan dan kebiasaan), penentuan alat instrument disesuaikan dengan aspek yang akan dinilai.
\end{abstract}

\begin{abstract}
:
Evaluation is a tool, which is used to measure the success level of a program. In measuring something, it must use appropriate tool based on the existing indicators. Evaluation in education is related to activity or process of education that becomes center of attention. The object of study is cognitive (knowledge and understanding), affective (attitudes and ideas), and psychomotoric (skills and habits), the determination of the instrument is associated with aspects that will be be assessed.
\end{abstract}

\section{Kata kunci: \\ Evaluasi, kognitif, afektif, psikomotik}

EVALUASI merupakan media untuk mengukur tingkat keberhasilan suatu program. Istilah lain yang dipakai adalah measurement yakni pengukuran untuk mengetahui keadaan terhadap sesuatu. ${ }^{1}$ Dalam melakukan suatu evaluasi harus memakai ukuranukuran tertentu atau indikator-indikator yang jelas sehingga hasilnya dapat dipertanggungjawabkan secara ilmiah. Misalnya, untuk mengukur panjang sesuatu, maka yang dipakai adalah meter, untuk mengukur berat sesuatu maka alat ukurnya adalah timbangan, thermometer untuk suhu badan dan untuk mengukur kamampuan seseorang manghapal Alquran di luar kepala alat ukurnya adalah hapalan dan lain-lain. ${ }^{2}$ Selain istilah di atas, terdapat istilah lain yang biasa dipergunakan untuk evaluasi seperti penilaian, ujian, ulangan dan lain sebagainya.

Dalam melakukan evaluasi, harus terdapat sasaran yang jelas. Evaluasi dalam pendidikan sasarannya adalah segala sesuatu yang bertalian dengan kegiatan atau proses pendidikan yang dijadikan titik pusat perhatian atau pengamatan, karena pihak penilai atau evaluator ingin memperoleh informasi tentang kegiatan atau proses pendidikan tersebut. ${ }^{3}$

Oleh karena itu, kegiatan evaluasi memiliki arti penting dalam dunia pendidikan untuk mengetahui tingkat keberhasilan yang telah dicapai. Untuk dapat mengukur tingkat keberhasilan, maka pertanyaan yang sering muncul sebelum melakukan 
penilaian ialah apa yang harus dinilai. Terhadap pertanyaan ini, maka kita kembali kepada unsur-unsur yang terdapat dalam proses pembelajaran. Ada beberapa unsur utama yang terdapat dalam proses pembelajaran yakni, tujuan, bahan, metode, dan alat serta penilain. ${ }^{4}$ Tujuan sebagai arah dari proses pembelajaran, pada hakekatnya adalah rumusan hasil-hasil yang harus dicapai setelah proses pembelajaran berakhir atau rumusan tingkah laku yang diharapkan dapat dikuasai oleh peserta didik setelah menempuh pengalaman belajarnya. Bahan adalah seperangkat pengetahuan yang harus dimilki oleh seorang peserta didik yang dijabarkan dalam bentuk kurikulum dan disampaikan dalam proses pembelajaran dengan target pencapaian tertentu. Metode dan alat adalah cara atau teknik yang dipergunakan untuk tujuan yang direncanakan dari awal. Sedangkan penilaian adalah upaya atau tindakan yang dilakukan untuk mengetahui sejauh mana tujuan yang telah ditargetkan tercapai atau tidak. Oleh karena itu, penilaian ini merupakan alat untuk mengukur apakah suatu program tercapai atau tidak.

Dalam melakukan evaluasi, ada dua aspek yang memegang peranan penting, yaitu subjek dan objek. Pada makalah ini hanya menguraikan secara singkat subjek evaluasi. Objek atau sasaran evaluasi adalah segala sesuatu yang menjadi titik pusat pengamatan karena penilai menginginkan informasi tentang sesuatu tersebut ${ }^{5}$ sehingga hasilnya dapat diketahui.

\section{PEMBAHASAN}

Sebelum dilakukan evaluasi, tentu didahului oleh proses. Nana Sudjana mengatakan bahwa proses adalah kegiatan yang dilakukan oleh siswa dalam mencapai tujuan pendidikan, sedangkan hasil belajar adalah kemampuan-kemampuan yang dimiliki oleh siswa setelah menerima pengalaman belajarnya. ${ }^{6}$ Horward Kingley sebagaimana yang dikutip oleh Nana Sudjana membagi tiga macam hasil belajar yaitu: (a) keterampilan dan kebiasaan, (b) pengetahuan dan pengertian, dan (c) sikap dan citacita. Tiap-tiap jenis hasil belajar dapat diisi dengan bahan yang ditetapkan dalam kurikulum. Selanjutnya, Nana Sudjana mengutip pendapat Gagne yang membagi lima kategori hasil belajar yaitu: (a) informasi verbal, (b) keterampilan intelektual, (c) strategi kognitif, (d) sikap, dan (e) keterampilan motoris. ${ }^{7}$

Dalam sistem pendidikan nasional, rumusan tujuan pendidikan tampaknya mengacu kepada klasifikasi hasil belajar rumusan Benyamin Bloom yang secara garis besarnya membaginya ke dalam tiga ranah yaitu: kognitif, afektif, dan psikomotoris. Secara rinci disebutkan bahwa tujuan pendidikan nasional adalah untuk mengembangkan potensi peserta didik agar menjadi manusia yang beriman dan bertakwa kepada Tuhan Yang Maha Esa, berakhlak mulia, sehat, berilmu, cakap kreatif, mandiri, dan menjadi warga negara yang demokratis serta bertanggung jawab. ${ }^{8}$

Mencermati rumusan tujuan pendidikan menurut undang-undang, maka secara garis besar ada tiga aspek yang dinilai yaitu: kognitif, afektif, dan psikomotoris, dan selanjutnya diuraikan satu persatu sebagai berikut. 


\section{Ranah Kognitif}

Sebelum mengukur sesuatu, terlebih dahulu kita harus memiliki batasan tertentu seperti:

1. Mengidentifikasi orang yang hendak diukur

2. Mengidentifikasi karakteristik (sifat-sifat) khas orang yang hendak diukur

3. Menetapkan prosedur yang hendak dipakai untuk dapat memberikan angkaangka pada karakteristik tersebut. ${ }^{9}$

Istilah kognitif berasal dari kata cognition artinya tindakan atau proses untuk mendapatkan/mengetahui sesuatu dengan rasio atau intuisi. ${ }^{10}$ Dengan demikian, kognisi adalah perolehan pengetahuan oleh seseorang. Dalam perkembangan selanjutnya, istilah ini diserap ke dalam bahasa Indonesia menjadi kognisi yang merupakan wilayah atau domain psikologis manusia yang meliputi setiap prilaku dan mental manusia yang berhubungan dengan pemahaman, pertimbangan, pemecahan masalah, dan kesengajaan. Dengan istilah lain, aspek kognitif merupakan bagian dari kognisi yang merupakan disiplin psikologi yang khusus membahas tentang penelitian dan pembahasan psikologi, termasuk di dalamnya proses penerimaan, pengolahan, penyimpanan, dan perolehan kembali informasi dari sistem memori (akal) manusia. ${ }^{11}$

Dalam pembahasan tentang rana kognitif, terdapat beberapa tipe yang menjadi pokok bahasannya sebagimana yang ditawarkan oleh Nana Sudjana yaitu:

\section{Tipe hasil belajar: Pengetahuan}

Istilah pengetahuan dimaksudkan sebagai terjemahan dari kata knowledge dalam taksonomi Bloom. Sekalipun demikian, maknanya tidaklah sepenuhnya benar, sebab dalam istilah tersebut termasuk pula pengetahuan faktual di samping pengetahuan hapalan atau untuk diingat seperti rumus, batasan, definisi, istilah, pasal dalam undang-undang, nama-nama tokoh, nama-nama kota yang kalau ditransfer ke dalam sistem pembelajaran agama merupakan hapalan terhadap ayat-ayat, hadishadis, kaidah dan sebagainya.

Sebagian ahli mengatakan bahwa tipe hasil belajar seperti ini termasuk kategori kognitif tingkat rendah. Meskipun demikian, tipe ini merupakan prasyarat bagi tipe hasil belajar berikutnya. Hapalan menjadi prasyarat bagi pemahaman, dan hal ini berlaku bagi semua bidang studi. Inilah barangkali yang mengilhami beberapa ulama besar dalam Islam sehingga banyak yang menghapal sebelum mereka mengkaji ilmu keislaman lebih mendalam. Mereka dalam mengemukakan argumen sangat kuat karena telah meghapal ayat-ayat atau hadis-hadis serta kaidah-kaidah. Hal ini juga berlaku dalam ilmu eksakta bahwa seseorang harus menghapal rumus-rumus matematika misalnya sehingga memudahkan melakukan analisis terhadap sesuatu.

Dalam menyusun item tes hapalan menurut para ahli tidaklah terlalu sukar, karena tinggal meminta untuk menyebutkan apa yang dikehendaki oleh si pembuat petanyaan. Akibatnya banyak para penyusun tes hasil belajar, secara tidak sengaja tergelincir atau terperosok masuk ke dalam kawasan ini. 
Menurut Nana Sudjana bahwa tes yang paling banyak dipakai untuk mengungkapkan aspek pengetahuan adalah tipe melengkapi, tipe isian, dan tipe banar-salah, karena lebih mudah menyusunnya, sehingga banyak pembuat tes memilih tipe ini. ${ }^{12}$

Kelemahan tipe ini karena terkadang kurang dipersiapkan dengan baik dan tergesa-gesa dalam membuat tes sehingga sering terjebak ke dalam pengungkapan pengetahuan hapalan saja. Aspek yang ditanyakan biasanya hanya fakta-fakta seperti nama orang, ibukota, defenisi dan lain sebagainya, dan hanya dituntut kesanggupan mengingatnya sehingga akibatnya jawabannya mudah ditebak.

\section{Tipe hasil belajar: Pemahaman}

Para ahli mengatakan bahwa tipe hasil yang lebih tinggi daripada pengetahuan adalah pemahaman. Misalnya seorang murid menjelaskan dengan susunan kalimatnya sesuai dengan hasil pemahamannya terhadap apa yang didengar, yang dibaca, memberi contoh lain dari yang dicontohkan, atau memberi contoh kasus yang lain. Kesanggupan memahami setingkat lebih tinggi dari pengetahuan. Dari hasil belajar tersebut, diharapkan terjadinya perubahan prilaku terjadi pada peserta didik. Menurut E. Mulyasa bahwa pada umumnya hasil belajar akan memberikan pengaruh dalam dua bentuk: (a) peserta didik akan mempunyai perspektif terhadap kekuatan dan kelemahannya atas prilaku yang diinginkan, dan (b) mereka mendapatkan bahwa prilaku yang diinginkan itu telah meningkat, baik setahap ataupun dua tahap, ${ }^{13}$ sehingga dari proses ini terjadi perubahan peningkatan dari tahap pengetahuan ke tahap pemahaman.

Nana Sudjana membagi pemahaman ke dalam tiga kategori. Pertama, tingkat terendah adalah pemahaman terjemahan, mulai dari terjemahan dalam arti yang sebenarnya, misalnya dari bahasa Inggris ke dalam bahasa Indonesia, mengartikan bendera merah puti dan lain sebagainya.

Kedua, pemahaman penafsiran, menghubungkan bagian-bagian terdahulu dengan yang diketahui berikutnya, atau menghubungkan beberapa bagian dari grafik dengan kejadian, membedakan yang pokok dengan yang bukan pokok.

Ketiga, atau tingkat tertinggi adalah pemahaman ekstrapolasi. Dengan ekstrapolasi diharapkan seseorang mampu melihat di balik yang tertulis, dapat memperluas persepsi terhadap sesuatu ${ }^{14}$ sehingga ia dapat mengembangkan makna yang terkandung dalam sutau pernyataan.

\section{Tipe hasil belajar: Aplikasi}

Yang dimaksud aplikasi dalam hal ini adalah penggunaan abstraksi pada situasi kongkret atau situasi khusus. Abstraksi tersebut bisa berupa ide, teori atau petunjuk teknis. Menerapkan abstraksi ke dalam situasi baru disebut aplikasi. Mengulangulang menerapkannya pada situasi lama akan beralih menjadi pengetahuan hapalan atau keterampilan. Suatu situasi tetap dianggap sebagai situasi baru apabila tetap terjadi pemecahan masalah. Kecuali itu, ada unsur lagi yang perlu masuk, yaitu abstraksi tersebut perlu berupa prinsip atau generalisasi, yakni sesuatu yang umum sifatnya untuk diterapkan pada situasi khusus. 


\section{Tipe hasil belajar: Analisis}

Tipe hasil belajar ini merupakan usaha memilah suatu integritas menjadi unsurunsur atau bagian-bagian sehingga jelas hierarkinya dan atau susunannya. Analisis merupakan kecakapan yang kompleks, yang memanfaatkan kecakapan dari tige tipe sebelumnya. Dengan analisis, diharapkan seseorang memiliki pemahaman yang komprehensif dan dapat memilahkan integritas menjadi bagian-bagian yang tetap terpa$\mathrm{du}$, untuk beberapa hal memahami prosesnya, untuk hal lain memahami cara kerjanya. Apabila seseorang kecakapan analisis tersebut telah dimiliki seseorang, maka ia akan dapat mengaplikasikannya pada situasi baru secara kreatif.

\section{Tipe hasil belajar: Sintesis}

Sintesis merupakan penyatuan unsur-unsur atau bagian-bagian ke dalam bentuk menyeluruh. Beberapa tipe sebelumnya telah disebutkan seperti pengetahuan hafalan, berpikir pemahaman, berpikir aplikasi, dan analisis dapat dipandang sebagai berpikir konvergen yang satu tingkat lebih rendah daripada berpikir divergen. Dalam berpikir konvergen pemecahan atau jawabannya akan sudah diketahui berdasarkan yang sudah dikenalnya. Sedangkan berpikir sintesis disebut divergen. Dalam berpikir divergen pemecahan atau jawabannya belum dapat dipastikan. Mensintesiskan unitunit tersebut tidak sama dengan mengumpulkannya ke dalam kelompok-kelompok besar. ${ }^{15}$ Berpikir sintesis merupakan salah satu terminal untuk menjadikan orang lebih kreatif. Sedangkan berpikir merupakan salah satu hasil yang hendak dicapai dalam pendidikan. Seseorang kreatif sering menemukan atau menciptakan sesuatu yang baru.

\section{Tes hasil belajar: Evaluasi}

Secara umum evaluasi diartikan sebagai penilaian/penaksiran terhadap pertumbuhan dan kemajuan peserta didik ke arah tujuan-tujuan yang telah ditetapkan dalam hukum ${ }^{16}$ dan hasil penilaian/evaluasi dapat dinyatakan secara kualitatif ataupun kuantitaif. Dengan demikian, evaluasi merupakan pemberian keputusan tentang nilai sesuatu yang boleh jadi dilihat dari sisi tujuan, cara bekerja, pemecahan, metode, materil dan lain-lain. Dilihat dari segi ini, maka dalam melakukan evaluasi perlu adanya suatu kriteria yang jelas dan terukur atau memiliki standar tertentu. Satu contoh tes dalam bentuk essay, standar atau kriteria tersebut muncul dalam bentuk frase "menurut pendapat saudara" atau "menurut teori tertentu". Frase pertama agak sulit menilai mutunya karena lingkup variasi kriterinya sangat luas. Sedangkan frase kedua agak lebih lebih mudah karena jelas standarnya yaitu adanya menunjuk teori tertentu. Jadi, dalam menyusun item tes hendaknya menyebutkan kriteria secara eksplisit.

Dalam mengetes kecakapan evaluasi, Nana Sudjana menawarkan setidaktidaknya enam kategori harus dimiliki seseorang yaitu:

1. Dapat memberikan evaluasi tentang ketepatan suatu karya atau dokumen;

2. Dapat memberikan evaluasi satu sama lain antara asumsi, evidensi, dan kesimpul- 
an. Dengan kecakapan ini, diharapkan seseorang mampu mengenal bagian-bagian serta keterpaduannya;

3. Dapat memahami nilai serta sudut pandang yang dipakai orang dalam mengambil suatu keputusan;

4. Dapat mengevaluasi suatu karya dengan memperbandingkannya dengan karya lain yang relevan;

5. Dapat mengevaluasi suatu karya dengan menggunakan suatu kriteria yang telah ditetapkan;

6. Dapat mengevaluasi suatu karya dengan menggunakan sejumlah criteria yang eksplisit.

Hasil belajar di bidang evaluasi tidak hanya meliputi aspek kognitif, tetapi juga meliputi apektif dan psikomotoris. Untuk melengkapi hasil di atas, berikut uraian tentang hasil belajar afektif.

\section{Ranah Afektif}

Afektif, merupakan ranah yang berkaitan dengan sikap dan nilai. Sebagian ahli mengatakan bahwa sikap seseorang dapat diramalkan perubahannya apabila seseorang memiliki penguasaan kognitif yang tinggi. Dalam kasus ujian nasional, setiap kali diselenggarakan oleh pemerintah sangat menonjol bahwa yang menjadi prioritas penilaian hanya mengukur ranah kognitif dan hampir melupakan ranah afektif. Ranah ini terkadang kurang mendapat perhatian dari pemerintah.

Memang para ahli mengakui bahwa alat-alat untuk mengukur segi afektif sangat sukar dikembangkan. ${ }^{17}$ Hal tersebut disebabkan karena sulitnya membuat pertanyaan yang berkaitan dengan afektif siswa terhadap mata pelajaran. Salah satu contoh soal kalau membuat pertanyaan ranah kognit adalah seperti, "apa yang dapat dilakukan oleh peserta didik", maka kalau soal dari segi ranah afektifnya pertanyaannya adalah seperti "apa yang mau dilakukan oleh peseta didik." Sebagai akibat dari sulitnya membuat pertanyaan yang bersifat afektif, maka para guru lebih banyak menilai ranah kognitif semata. Tipe hasil belajar afektif tampak pada siswa dalam berbagai tingkah laku seperti perhatiannya terhadap pelajaran, disiplin, motivasi belajar, menghargai guru, dan teman-teman sekelas, kebiasaan belajar, dan hubungan sosial.

Daryanto mengemukakan ranah afektif meliputi lima kemampuan yaitu:

1. Menerima (receiving). Dalam kondisi ini, peserta didik memiliki kesediaan atau kemauan untuk ikut dalam fenomena atau stimulus khusus (kegiatan dalam kelas, musik, baca buku dan lain sebagainya). Sikap ini memperlihatkan adanya minat peserta didik untuk melakukan sesuatu.

2. Menjawab (responding). Kondisi ini berkaitan dengan partisipasi peserta didik. Pada tingkat ini, peserta didik tidak hanya menghadiri suatu fenomena tertentu, tetapi juga mereaksi terhadapnya dengan salah satu cara. Hasil belajar dalam jenjang ini dapat menekankan kemauan untuk menjawab (misalnya secara sukarela membaca buku tanpa ditugaskan) atau kepuasan dalam menjawab (misalnya untuk kenikmatan atau kegembiraan.)

3. Menilai (valuing). Jenjang ini bertalian denga nilai yang dikenakan siswa terhadap 
suatu objek, fenomena, atau tingkah laku tertentu. Jenjang ini mulai dari hanya sekedar penerimaan nilai (ingin memperbaiki keterampilan kelompok) sampai ke tingkat komitmen yang lebih tinggi (menerima tanggung jawab untuk fungsi kelompok yang lebih efektif).

4. Organisasi (organization). Tingkat ini berhubungan dengan menyatukan nilai-nilai yang berbeda, menyelesaikan/memecahkan konflik di antara nilai-nilai itu dan mulai membentuk suatu sistem nilai yang konsisten secara internal.

5. Karakteristik dengan suatu nilai atau kompleks nilai (characterization by a value or value compelx). Pada jenjang ini, individu memiliki sistem nilai yang mengontrol tingkah lakunya untuk suatu waktu yang cukup lama sehingga membentuk karakteristik "pola hidup". Jadi, tingkah lakunya menetap, konsisten, dan dapat diramalkan. Hasil belajar meliputi sangat banyak kegiatan, tetapi penekanan lebih besar diletakkan pada kenyataan bahwa tingkah laku itu menjadi ciri khas atau karakteristik peserta didik.

\section{Ranah Psikomotoris}

Kesempurnaan ranah psikomotoris dapat diukur dari sejauhmana rana kognitf dan afektif memberi pengaruh yang signifikan. Kecakapan psikomotis seseorang adalah segala keterampilan aktifitas jasmaniah yang kongkrit dan mudah diamati, baik kuantitasnya maupun kualitasnya, karena sifatnya sangat terbuka untuk diamati. Kecakapan psikomotoris peserta didik merupakan manifestasi wawasan pengetahuan yang dimiliki dengan tingkat kesadaran, sikap mental, dan keterampilannya. Dalam pendidikan Islam, penilaian terhadap aspek psikomotorisnya terutama ditekankan pada unsur pokok prilaku beribadah seseorag, misalnya salat, puasa, naik haji, membaca Alquran, dan semisalnya. ${ }^{18}$

Evaluasi dalam aspek psikomotoris dapat dibagi atas lima taraf, yaitu: (a) persepsi, yaitu mencakup kemampuan menafsirkan rangsangan, (b) kesiapan yakni mencakup tiga aspek yaitu: intelektual, fisis, dan emosional, (c) gerakan terbimbing, yakni kemampuan yang merupakan bagian dari keterampilan yang lebih kompleks, (d) gerakan terbiasa yakni terampil melakukan suatu perbuatan, dan (e) gerakan kompleks, yakni melakukan perbuatan motoris yang kompleks dengan lancar, luwes, gesit, atau lincah. ${ }^{19}$

Versi lain membagi hasil belajar psikomotoris tampak dalam bentuk keterampilan (skill) dan kemampuan bertindak individu ke dalam enam tingkatan keterampilan yaitu:

1. Gerakan refleks (keterampilan pada gerakan yang tidak sadar);

2. Keterampilan pada gerakan-gerakan dasar;

3. Kemampuan perseptual, termasuk di dalamnya membedakan visual auditif, motoris, dan lain-lain;

4. Kemampuan di bidang fisik, misalnya kekuatan, keharmonisan, dan ketepatan;

5. Gerakan-gerakan skill, mulai dari keterampilan sederhana sampai pada keterampilan yang kompleks;

6. Kemampuan yang berkenan dengan komunikasi. ${ }^{20}$ 
Hasil belajar yang dikemuakan di atas sebenarnya tidak berdiri sendiri, tetapi selalu memiliki keterkaitan anatara satu dengan yang lainnya. Misalnya, seseorang yang kognisinya baik, maka sangat mungkin sikap afektifnya dan psikomotorisnya juga akan meningkat.

\section{SIMPULAN}

Setelah diuraikan secara singkat tentang aspek-aspek yang dinilai dalam pendidikan, maka kesimpulannya sebagai berikut:

1. Adapun objek-objek evaluasi dalam pendidikan adalah ranah kognitif, ranah afektif, dan ranah psikomotoris

2. Adapun cara mengevaluasinya adalah dengan menyesuaikan objek penilaian dalam pendidikan. Kalau yang dinlai adalah kognitif, maka dibuat alat evaluasi untuk mengetahui tingkat penguasaan peserat didik terhadap bahan pembelajaran, kalau afektifnya maka dinlihat sikap peserta didik terhadap apa yang ditugaskan dan jika psikomotorisnya, maka dilihat sejauhmana peserta didik dapat mempraktekkan dalam kehidupannya sehari-hari apa yang telah diajarkan.

\section{CATATAN AKHIR:}

1. Lihat Robert L. Thorndike dan Elizabeth P. Hagen, Measurement and Evaluation in Psycholoy and Education Fourth Edition, New York John and Sons. t.th, h. 3.

2. Lihat Mappanganro, Implementasi Pendidikan Islam di Sekolah, cet.I; Ujung Pandang: Yayasan Ahkam, h. 99.

3. Anas Sudijono, Pengantar Evaluasi Pendidikan, Edisi 6, Jakarta: Rajawali Pers, 2006, h. 25.

4. Nana Sudjana, Penilaian Hasil Proses Belajar Mengajar, cet. XI: Bandung: Remaja Rosdakarya, 2006, h. 22.

5. Suharsimi Arikunto, Dasa-Dasar Evaluasi Pendidikan, cet. VIII; Jakarta: Bumi Aksara, 2008, h. 20.

6. Nana Sudjana, op. cit.

7. Ibid.

8. Wiji Suwarno, Dasar-Dasar Ilmu Pendidikan, cet. I: Yogyakarta: Ar-Ruz Media, 2006, h. 32.

9. Daryanto, Evaluasi Pendidikan, cet. IV; Jakarta: Rineka Cipta, 2007, h. 101.

10. A.S Hornby, Oxford Advanced Leaner's Dictionary, Fourth Edition; Oxford: Oxford University, 1989, h. 219.

11. Robert L. Thorndike, op. cit, h. 336-337.

12. Nana Sudjana, op.cit, h. 24.

13. E. Mulyasa, Kurikulum yang Disempurnakan, cet. I; Bandung: Remaja Rosdakarya, 2006, h. 244.

14. Nana Sudjana, op.cit.

15. Ibid. h. 28.

16. Harjanto, Perencanaan Pengajaran, cet. V; Jakarta: Rineka Cipta, 2006, h. 277.

17. W.James Pophan dan Eva L. Baker, Estabilishing Instructional Golols and Systematic Instruction diterjemahkan oleh Amirul Hadi dengan judul Teknik Mengajar Secara Sistematis, cet. IV; Jakarta: Rineka Cipta, 2008, h.33.

18. Mappanganro, loc cit. 
19. Slameto, Belajar dan faktor-faktor yang Mempengaruhinya, cet. IV; Jakarta: Rineka Cipta, 2003, h.17-18.

20. Nana Sudjana, op.cit, h. 31.

\section{DAFTAR PUSTAKA:}

Arikunto, Suharsimi, Dasa-Dasar Evaluasi Pendidikan, cet. VIII; Jakarta: Bumi Aksara, 2008.

Daryanto, Evaluasi Pendidikan, cet. IV; Jakarta: Rineka Cipta, 2007.

Harjanto, Perencanaan Pengajaran, cet.V; Jakarta: Rineka Cipta, 2006.

Hornby, A.S., Oxford Advanced Leaner's Dictionary, Fourth Edition, Oxford: Oxford University, 1989.

Mappanganro, Implementasi Pendidikan Islam di Sekolah, cet. I; Ujung Pandang: Yayasan Ahkam.

Mulyasa, E., Kurikulum yang Disempurnakan, cet. I; Bandung: Remaja Rosdakarya, 2006.

Pophan, W. James dan Eva L. Baker, Estabilishing Instructional Gols and Systematic Instruction diterjemahkan oleh Amirul Hadi dengan judul Teknik Mengajar Secara Sistematis, cet. IV; Jakarta: Rineka Cipta, 2008.

Slameto, Belajar dan Faktor-Faktor yang Mempengaruhinya, cet. IV; Jakarta: Rineka Cipta, 2003.

Sudijono, Anas, Pengantar Evaluasi Pendidikan, Edisi 6, Jakarta: Rajawali Pers, 2006.

Sudjana, Nana, Penilaian Hasil Proses Belajar Mengajar, cet. XI: Bandung: Remaja Rosdakarya, 2006.

Suwarno, Wiji, Dasar-Dasar Ilmu Pendidikan, cet. I: Yogyakarta: Ar-Ruz Media, 2006.

Thorndike, Robert L. dan Elizabeth P. Hagen, Measurement and Evaluation in Psycholoy and Education, Fourth Edition, New York: John and Sons. 